\title{
Influence of the Changjiang River on the light absorption properties of phytoplankton from the East China Sea
}

\author{
S. Q. Wang ${ }^{1}$, J. Ishizaka ${ }^{2}$, H. Yamaguchi ${ }^{3}$, S. C. Tripathy ${ }^{4}$, M. Hayashi ${ }^{1}$, Y. J. Xu' ${ }^{2}$, Y. Mino ${ }^{2}$, T. Matsuno ${ }^{5}$, \\ Y. Watanabe ${ }^{6}$, and S. J. Yoo ${ }^{7}$ \\ ${ }^{1}$ Graduate School of Environmental Studies, Nagoya University, Nagoya, Japan \\ ${ }^{2}$ Hydrospheric Atmospheric Research Center, Nagoya University, Nagoya, Japan \\ ${ }^{3}$ Earth Observation Research Center, Japan Aerospace Exploration Agency, Tsukuba, Japan \\ ${ }^{4}$ National Centre for Antarctic and Ocean Research, Goa, India \\ ${ }^{5}$ Research Institute for Applied Mechanics, Kyushu University, Kasuga, Japan \\ ${ }^{6}$ The General Environmental Technos Co., LTD, Osaka, Japan \\ ${ }^{7}$ Korea Institute of Ocean Science and Technology, Ansan, Korea
}

Correspondence to: J. Ishizaka (jishizak@hyarc.nagoya-u.ac.jp)

Received: 15 August 2013 - Published in Biogeosciences Discuss.: 29 August 2013

Revised: 5 February 2014 - Accepted: 11 February 2014 - Published: 3 April 2014

\begin{abstract}
Phytoplankton light absorption properties were investigated at the surface and subsurface chlorophyll $a$ maximum (SCM) layer in the East China Sea (ECS), a marginal sea which is strongly influenced by the Changjiang discharge in summer. Results from ECS were compared with those from the Tsushima Strait (TS) where the influence of Changjiang discharge is less. The probable controlling factors, packaging effect (cell size) and pigment composition of total chlorophyll $a$ (Tchl $a$ )-specific absorption coefficient $\left(a_{\mathrm{ph}}^{*}(\lambda)\right)$ were examined by the corresponding measurements of pigments identified by high-performance liquid chromatography. We observed distinct phytoplankton size structure and thereby absorption properties between ECS and TS. At the surface, mixed populations of micro-, nanoand pico-phytoplankton were recorded in ECS while picophytoplankton dominated in TS, generating a lower average $a_{\mathrm{ph}}^{*}(\lambda)$ in ECS than in TS. Within SCM, average $a_{\mathrm{ph}}^{*}(\lambda)$ was higher in ECS than in TS because of the dominance of nano- and micro-phytoplankton in ECS and TS, respectively. By pooling surface and SCM samples, we found regular trends in phytoplankton size-fraction versus Tchl $a$; and correlations between $a_{\mathrm{ph}}^{*}(\lambda)$ and Tchl $a$ consistent with previous observations for the global ocean in TS but not in ECS. In ECS phytoplankton size-fraction was not correlated with Tchl $a$, which consequently caused poor relationships between $a_{\mathrm{ph}}^{*}(\lambda)$ and Tchl $a$. The abnormal values mainly orig-
\end{abstract}

inated from the surface low-salinity waters and SCM waters beneath them. At high Tchl $a, a_{\mathrm{ph}}^{*}(\lambda)$ of these samples was substantially higher compared to the values in TS and from the global regressions, which was attributable to the lower micro-phytoplankton fraction, and higher nano- and/or pico-phytoplankton fractions in ECS. These observations indicated that the distinct light absorption properties of phytoplankton in ECS were possibly influenced by the Changjiang discharge. Our findings imply that general bio-optical algorithms proposed based on the correlations between $a_{\mathrm{ph}}^{*}(\lambda)$ and Tchl $a$ or the patterns in size-fraction versus Tchl $a$ are not applicable in ECS, and need to be carefully considered when using these general algorithms in river-influenced regions.

\section{Introduction}

Phytoplankton light absorption is a major determinant of the optical properties of oceanic and coastal waters. This process can change the underwater light fields, modulate photosynthesis, and alter the ocean colour (Gordon et al., 1988; Morel, 1988). Knowledge of phytoplankton light absorption and its variation is thus vital for understanding the optical variability of water bodies, and therefore important for improving a variety of bio-optical algorithms, such as for remote 
sensing of chlorophyll $a$ concentration (Chl $a$ ) (Garver and Siegel, 1997; He et al., 2000), primary production (Platt and Sathyendranath, 1988; Ishizaka, 1998), and phytoplankton size classes (Ciotti and Bricaud, 2006; Hirata et al., 2008; Devred et al., 2011).

In recent decades, phytoplankton light absorption has been extensively investigated in various regions of the world ocean. It is well documented that the phytoplankton absorption coefficient, $a_{\mathrm{ph}}(\lambda)$, is positively correlated with $\mathrm{Chl} a$ and that this correlation holds fairly well for various water bodies (Cleveland, 1995; Babin et al., 2003; Bricaud et al., 2004). Furthermore, the Chl $a$-specific absorption coefficient, $a_{\mathrm{ph}}^{*}(\lambda)\left(a_{\mathrm{ph}}(\lambda)\right.$ normalized to Chl $\left.a\right)$, and its temporal/spatial variations have been reported for various water bodies (Babin et al., 1993; Bricaud et al., 1995; Suzuki et al., 1998; Harimoto et al., 1999; Stæhr et al., 2004). In general, $a_{\mathrm{ph}}^{*}(\lambda)$ decreases with an increase in Chl $a$. The decrease in $a_{\mathrm{ph}}^{*}(\lambda)$ is due to pigment "packaging" that has often been referred to as the "packaging effect" or "package effect" (Bannister, 1974; Kirk, 1975). The packaging effect, together with phytoplankton pigment composition, have been suggested to be the major factors causing the variability in $a_{\mathrm{ph}}^{*}(\lambda)$ (Morel and Bricaud, 1981; Stuart et al., 1998; Lohrenz et al., 2003). These two factors are different among and within phytoplankton populations growing under various environmental conditions such as nutrient levels and irradiance (Bricaud, 2004; Stæhr et al., 2004).

The packaging effect is usually higher in larger phytoplankton, producing lower $a_{\mathrm{ph}}^{*}(\lambda)$. Conversely, the packaging effect is less in small phytoplankton and results in higher $a_{\mathrm{ph}}^{*}(\lambda)$. Changes in the phytoplankton size structure have been reported to primarily explain variations in $a_{\mathrm{ph}}^{*}(\lambda)$ (Ciotti et al., 2002; Bricaud et al., 2004). Sathyendranath et al. (2001) expressed $a_{\mathrm{ph}}(\lambda)$ as the sum of absorption by two populations with distinct cell sizes, and this model was further extended to the three-population model by Brewin et al. (2011). More recently, absorption models based on two or three populations have been improved to estimate $a_{\mathrm{ph}}^{*}(\lambda)$ of different populations as well as to derive size-fractions from $a_{\mathrm{ph}}(\lambda)$ (Devred et al., 2006, 2011). Note that these models are based on the hypothesis that small and large cells dominate in low and high Chl $a$ waters, respectively, which has been clearly observed in the global ocean (Brewin et al., 2010; Hirata et al., 2011).

In coastal waters, however, the validity of the above hypothesis is not clear. Because of the dynamic hydrographic conditions (e.g., river discharge, upwelling and mixing), the optical properties of coastal waters are complex (Babin et al., 2003). Some studies have shown that freshwater discharges could significantly change the optical properties of seawater, especially the light absorption budget among phytoplankton, detritus and coloured dissolved organic matter (Babin et al., 2003; D'Sa et al., 2006; Odriozola et al., 2007; Matsuoka et al., 2011; Brunelle et al., 2012). However, few studies specif- ically focus on the variability in phytoplankton absorption properties and the controlling factors causing the variability in regions influenced by riverine discharge. Here we describe the scenario for the East China Sea (ECS), which is one of the largest marginal seas in the western North Pacific. The ECS is significantly influenced by river discharge from the Changjiang (Gong et al., 1996). In summer, it receives enormous amounts of freshwater containing very high concentrations of nitrogen (Gong et al., 1996; Siswanto et al., 2008). The nutrient-rich freshwater mixes with the surrounding high-salinity waters, forming the Changjiang diluted water (CDW) with a thickness of about $10-20 \mathrm{~m}$ in the mid-shelf area, which extends offshore and moves northeastward near Jeju Island to the Tsushima Strait (TS) (Yamaguchi et al., 2012). It has been suggested that CDW enhances $\mathrm{Chl} a$, resulting in high primary production in the upper layer of ECS (Hama et al., 1997; Yamaguchi et al., 2012). Zhou et al. (2008) and $\mathrm{Li}$ et al. (2009) were able to show that Changjiang freshwater in the estuary and adjacent coastal waters can modulate phytoplankton community structure. One would expect therefore that Changjiang freshwater discharge can have a strong influence on phytoplankton light absorption in ECS.

TS, which is a narrow and shallow strait between Korea and Japan, connects ECS and the Sea of Japan. Water in TS originates partly from the Kuroshio but mainly from ECS in summer (Guo et al., 2006). Freshwater and nutrients are transported from ECS through TS to the Sea of Japan (Isobe et al., 2002; Morimoto et al., 2009). Yamaguchi et al. (2012) observed that about 2 months was required for CDW to reach TS, where the increase in surface Chl $a$ was very small, with a peak in September. Morimoto et al. (2009) suggested that when CDW extended into TS, nutrients were consumed by phytoplankton and depleted. These studies imply that the influence of Changjiang freshwater on phytoplankton in TS may be weak.

We hypothesize that the phytoplankton absorption properties in ECS, which is strongly influenced by the Changjiang freshwater, may be different from those in TS in summer. Hence, this study aims at investigating the difference(s) in (1) phytoplankton light absorption between ECS and TS at both surface and subsurface Chl $a$ maximum (SCM); (2) relationship between total $\mathrm{Chl} a\left(\mathrm{Tchl} a\right.$ ) with $a_{\mathrm{ph}}(\lambda)$ and $a_{\mathrm{ph}}^{*}(\lambda)$ for all samples from surface and SCM in both ECS and TS, and find the probable controlling factors causing the difference(s). Difference(s) in phytoplankton light absorption between ECS and TS have been discussed on the basis of the analysis of high-performance liquid chromatography (HPLC)-derived phytoplankton size structure, packaging effect and pigment composition. 


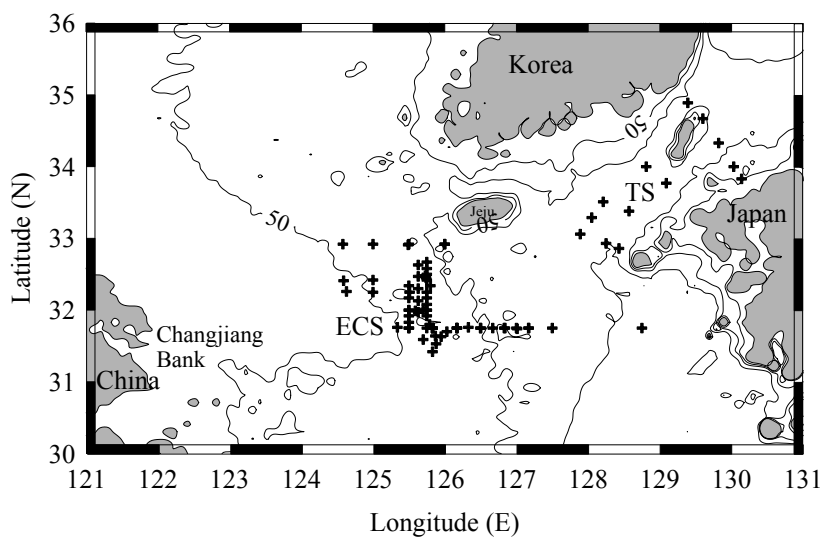

Fig. 1. Locations of the sampling stations in the Tsushima Strait (TS) and in the East China Sea (ECS).

\section{Materials and methods}

\subsection{Sampling}

Sampling in TS was conducted during cruises in July 2008 aboard the T/V Nagasaki maru and during four cruises aboard the R/V Tansei maru and the T/V Nagasaki maru in ECS during August 2008 and July 2009-2011, respectively. The locations of sampling stations are shown in Fig. 1. Water samples at discrete depths were collected using Niskin bottles (12 L on R/V Tansei maru; $5 \mathrm{~L}$ on T/V Nagasaki maru) mounted on a CTD/rosette system. Depths of the SCM which varied from 10 to $30 \mathrm{~m}$ were determined from the vertical fluorescence profiles obtained from CTD. Samples collected at the surface and SCM were used to measure $a_{\mathrm{ph}}(\lambda)$ and pigment concentrations.

\subsection{Measurement of absorption coefficient}

The quantitative filter technique (QFT) was used to determine $a_{\mathrm{ph}}(\lambda)$ (Mitchell, 1990). Water samples $(0.3-1 \mathrm{~L})$ were filtered through Whatman $\mathrm{GF} / \mathrm{F}$ glass fibre filters $(25 \mathrm{~mm})$ under low vacuum pressure $(<0.01 \mathrm{MPa})$. The optical density of total particles retained on the filter $\left(\mathrm{OD}_{\mathrm{p}}(\lambda)\right)$ were kept below 0.3 by adjusting the filtration volume. Subsequently, $\mathrm{OD}_{\mathrm{p}}(\lambda)$ was measured between 350 and $750 \mathrm{~nm}$ at $1 \mathrm{~nm}$ intervals, using a dual beam multi-purpose spectrophotometer (MPS-2400, Shimadzu Inc.). A blank filter soaked with $0.2 \mu \mathrm{m}$-filtered seawater (FSW) was used as the reference. To correct the path length amplification effect caused by multiple scattering in the glass fibre filter, the following equation was utilized according to Cleveland and Weidemann (1993):

$\mathrm{OD}_{\mathrm{s}}(\lambda)=0.378 \mathrm{OD}_{\mathrm{p}}(\lambda)+0.523 \mathrm{OD}_{\mathrm{p}}(\lambda)^{2}$,

where $\mathrm{OD}_{\mathrm{s}}(\lambda)$ is the optical density of particulate matter in suspension. The absorption coefficient of the total particles $\left(a_{\mathrm{p}}(\lambda)\right)$ was calculated using the following equation:

$a_{\mathrm{p}}(\lambda)=2.303 \mathrm{OD}_{\mathrm{s}}(\lambda) S / V$,

where 2.303 is the factor used to convert $\log _{10}$ to $\log _{e}, S$ is the filter clearance area $\left(\mathrm{m}^{2}\right)$, and $V$ is the filtered volume $\left(\mathrm{m}^{3}\right)$. The ratio of $S$ to $V$ approximates the geometrical light pass length.

After measurements of the optical density of the total particles, the filters were soaked in methanol for at least $24 \mathrm{~h}$ to extract phytoplankton pigments, and then rinsed with FSW. The absorbance of a decolourized filter was re-measured using the same method to obtain the optical density of the non-phytoplankton particles (Kishino et al., 1985). Similarly, the absorption coefficient of non-phytoplankton particles $\left(a_{\mathrm{nph}}(\lambda)\right)$ was determined using Eq. (1) and (2). $a_{\mathrm{ph}}(\lambda)$ was then obtained from the following equation:

$a_{\mathrm{ph}}(\lambda)=a_{\mathrm{p}}(\lambda)-a_{\mathrm{nph}}(\lambda)$.

The values reported in this study are averages from duplicate measurements. $a_{\mathrm{ph}}^{*}(\lambda)$ was calculated by normalizing $a_{\mathrm{ph}}(\lambda)$ to Tchl $a$ measured by HPLC. Tchl $a$ refers to the sum of Chl $a$ and divinyl Chl $a$.

\subsection{Pigment measurements and pigment-based phytoplankton size structure}

Water samples for pigment concentrations were filtered onto $25 \mathrm{~mm}$ Whatman GF/F glass fibre filters under low vacuum pressure $(<0.01 \mathrm{MPa})$. Filtered volumes of most of samples were $\sim 1 \mathrm{~L}$. The filters were immediately frozen in liquid nitrogen, and were then stored at $-80^{\circ} \mathrm{C}$ for subsequent laboratory analysis. Pigments were analysed by reverse-phase HPLC with a Zorbax Eclipse XDB-C8 column $(150 \mathrm{~mm} \times 4.6 \mathrm{~mm}, 3.5 \mu \mathrm{m}$; Agilent Technologies), and 19 pigments were separated and quantified following the method of Van Heukelem and Thomas (2001).

Diagnostic pigment analysis (DPA) was used to estimate Tchl $a$ fractions of pico- $(<2 \mu \mathrm{m})$, nano- $(2-20 \mu \mathrm{m})$ and micro-phytoplankton $(>20 \mu \mathrm{m})$, from HPLC pigment data. The DPA approach was originally proposed by Vidussi et al. (2001), and refined by Uitz et al. (2006). Briefly, seven marker pigments (MP) (i.e., fucoxanthin (Fuco), peridinin (Per), 19'-hexanoyloxyfucoxanthin (Hex), 19'butanoyloxyfucoxanthin (But), alloxanthin (Allo), chlorophyll $b(\mathrm{Chl} b)$, and zeaxanthin (Zea)) were selected as diagnostic pigments of distinct phytoplankton groups and were used to calculate Tchl $a$ fractions of three size classes (detailed pigment taxonomic significance reported previously by Vidussi et al., 2001 and Uitz et al., 2006). Subsequently, Hirata et al. (2008) further revised the approach of Uitz et al. (2006) to account for the occurrence of $\mathrm{Chl} b$ in larger eukaryotes, e.g., chlorophytes (nano-phytoplankton). According to Hirata et al. (2008), the size-fractions of each size class can be expressed as

$f_{\text {micro }}=(1.41$ Fuco +1.41 Per $) / \mathrm{DP}$ 


$$
f_{\text {nano }}=(0.60 \mathrm{Allo}+0.35 \mathrm{But}+1.27 \mathrm{Hex}+1.01 \mathrm{Chl} b) / \mathrm{DP}
$$

$f_{\text {pico }}=0.86 Z$ ea $/ \mathrm{DP}$,

where DP is the sum of the weighted concentrations of all diagnostic pigments:

$$
\begin{aligned}
\mathrm{DP} & =1.41 \mathrm{Fuco}+1.41 \mathrm{Per}+0.60 \mathrm{Allo}+0.35 \mathrm{But} \\
& +1.27 \mathrm{Hex}+1.01 \mathrm{Chl} b+0.86 \mathrm{Zea} .
\end{aligned}
$$

The numerical coefficients used in the above equations were derived by multiple regressions (Uitz et al., 2006), and represent the ratios of Tchl $a$ to each diagnostic pigment. Hirata et al. (2008) suggested that a particular phytoplankton size class was dominant if its fraction was $>0.45$. It should be noted that there are some potential anomalies in DPA, e.g., in some cases, a given diagnostic pigment possibly occurs in two size classes. Despite these potential limitations, DPA is a useful approximation, and the results are reasonably robust at a global as well as at a regional scale.

\subsection{Packaging effect index and total pigment absorption}

The packaging effect index, $Q_{\mathrm{a}}^{*}(\lambda)$, is defined as the ratio of the in vivo absorption coefficient $\left(a_{\mathrm{ph}}(\lambda)\right)$ to the absorption coefficient of the same cellular material in solution $\left(a_{\text {sol }}(\lambda)\right)$ (Bricaud et al., 2004). The computation is expressed as follows:

$Q_{\mathrm{a}}^{*}(\lambda)=a_{\mathrm{ph}}(\lambda) / a_{\mathrm{sol}}(\lambda)$,

The theoretical maximum and minimum values of $Q_{\mathrm{a}}^{*}(\lambda)$ are 1 and 0 , and correspond to conditions without a packaging effect and with the maximal packaging effect, respectively. Bricaud et al. (2004) found that $Q_{\mathrm{a}}^{*}(\lambda)$ was $>1$ for many samples, indicating that $a_{\text {sol }}(\lambda)$ reconstructed from all individual pigments was systematically lower than measured $a_{\mathrm{ph}}(\lambda)$. They argued that differences between measured and reconstructed absorption spectra could be attributed to missing pigments or other light-absorbing compounds extracted by methanol but not measured by HPLC. Considering the missing absorption term, $a_{\text {sol }}(\lambda)$ is calculated as

$a_{\mathrm{sol}}(\lambda)=\sum C_{i} a_{\mathrm{pigm}, i}^{*}(\lambda)+a_{\mathrm{miss}}(\lambda)$

where $C_{i}$ and $a_{\mathrm{pigm}, i}^{*}(\lambda)$ are the concentration and the pigment-specific absorption coefficient of the $i$ th pigment, respectively, and $a_{\text {miss }}(\lambda)$ is the missing absorption. In this study, $a_{\text {miss }}(440)$ was estimated according to Bricaud et al. (2004), and then $Q_{\mathrm{a}}^{*}(440)$ was calculated.

The total pigment-specific absorption coefficient is defined as Tchl $a$ normalized absorption coefficient of all the pigments (Bricaud et al., 2004), as in Eq. (10):

$a_{\mathrm{pigm}}^{*}(\lambda)=\sum C_{i} a_{\mathrm{pigm}, i}^{*}(\lambda) / \mathrm{Tchl} a$.
Linear regression analysis was performed to assess the relative contribution to the variation in $a_{\mathrm{ph}}^{*}(\lambda)$ from the packaging effect and pigment composition, taking $a_{\mathrm{ph}}^{*}(\lambda)$ as the dependent variable and $Q_{\mathrm{a}}^{*}(\lambda)$ or $a_{\text {pigm }}^{*}(\lambda)$ as the independent variable. Note that the approach used to obtain $a_{\text {pigm }}^{*}(\lambda)$ was independent of $a_{\mathrm{ph}}^{*}(\lambda)$, whereas the approach used for $Q_{\mathrm{a}}^{*}(\lambda)$ depended on $a_{\mathrm{ph}}^{*}(\lambda)$. In addition, the analyses performed in this study mainly focused on the $440 \mathrm{~nm}$ because the effects of both pigment packaging and composition are more pronounced in the blue region (Stuart et al., 1998).

\section{Results}

\subsection{Variations in Tchl $a$}

Tchl $a$ in the Tsushima Strait surface (TS_S), Tsushima Strait SCM (TS_SCM), East China Sea surface (ECS_S), and East China Sea SCM (ECS_SCM) displayed clear differences (Table 1). The average Tchl $a$ in TS_S and TS_SCM was lower than that of ECS_S and ECS_SCM, respectively. The difference between the average Tchl $a$ values in ECS_S and ECS_SCM was larger than the difference between the corresponding values in TS_S and TS_SCM. The coefficient of variation of Tchl $a$ was higher and similar in TS_SCM, ECS_S and ECS_SCM whereas it was lowest in TS_S.

\subsection{Variations of absorption coefficient}

The average $a_{\mathrm{ph}}(\lambda)$ was clearly different in TS_S, TS_SCM, ECS_S and ECS_SCM (Table 1 and Fig. 2a). The average $a_{\mathrm{ph}}(\lambda)$ was lowest in TS_S and much higher in ECS_S. The average $a_{\mathrm{ph}}(\lambda)$ in TS_SCM was also much lower than in ECS_SCM. The difference in average $a_{\mathrm{ph}}(\lambda)$ between the surface and SCM was larger in ECS than in TS.

As in previous studies (Bricaud et al., 1995, 2004), $a_{\mathrm{ph}}(440)$ and $a_{\mathrm{ph}}(675)$ were positively correlated with Tchl $a$ in TS and ECS (Fig. 3a, b). Here, $a_{\mathrm{ph}}(\lambda)$ of the surface and SCM waters were combined for analysis. The fitted power law functions were as follows. For TS

$$
\begin{aligned}
& a_{\mathrm{ph}}(440)=0.0436 \mathrm{Tchl} a^{0.626}, \\
& \left(R^{2}=0.871, N=25\right) \\
& a_{\mathrm{ph}}(675)=0.0192 \mathrm{Tchl} a^{0.852}, \\
& \left(R^{2}=0.930, N=25\right)
\end{aligned}
$$

and for ECS,

$$
\begin{aligned}
& a_{\mathrm{ph}}(440)=0.0667 \mathrm{Tchl} a^{0.885}, \\
& \left(R^{2}=0.861, N=118\right) \\
& a_{\mathrm{ph}}(675)=0.0252 \mathrm{Tchl} a^{1.007}, \\
& \left(R^{2}=0.898, N=118\right)
\end{aligned}
$$


Table 1. Comparisons of Tchl $a, a_{\mathrm{ph}}(440), a_{\mathrm{ph}}(675), a_{\mathrm{ph}}^{*}(440), a_{\mathrm{ph}}^{*}(675)$ and the ratio of $a_{\mathrm{ph}}^{*}(440)$ to $a_{\mathrm{ph}}^{*}(675)$ among the Tsushima Strait surface (TS_S), Tsushima Strait SCM (TS_SCM), East China Sea surface (ECS_S), and East China Sea SCM (ECS_SCM). Max: maximum; Min: minimum; Ave: average; SD: standard deviation; CV: coefficient of variation.

\begin{tabular}{lllllll}
\hline Variable & Location & Max & Min & Ave & SD & CV \\
\hline \multirow{3}{*}{ Tchl $a\left(\mathrm{mg} \mathrm{m}^{-3}\right)$} & TS_S & 0.24 & 0.12 & 0.18 & 0.05 & 26.4 \\
& TS_SCM & 3.06 & 0.58 & 1.33 & 0.78 & 58.3 \\
& ECS_S & 2.22 & 0.10 & 0.88 & 0.53 & 59.5 \\
& ECS_SCM & 6.10 & 0.74 & 2.48 & 1.31 & 52.9 \\
$a_{\mathrm{ph}}(440)\left(\mathrm{m}^{-1}\right)$ & TS_S & 0.023 & 0.008 & 0.015 & 0.004 & 27.9 \\
& TS_SCM & 0.108 & 0.029 & 0.052 & 0.022 & 41.6 \\
& ECS_S & 0.164 & 0.009 & 0.066 & 0.046 & 69.7 \\
$a_{\mathrm{ph}}(675)\left(\mathrm{m}^{-1}\right)$ & ECS_SCM & 0.394 & 0.047 & 0.144 & 0.068 & 47.3 \\
& TS_S & 0.006 & 0.003 & 0.004 & 0.001 & 25.2 \\
& TS_SCM & 0.052 & 0.014 & 0.025 & 0.011 & 46.1 \\
$a_{\mathrm{ph}}^{*}(440)\left(\mathrm{m}^{2} \mathrm{mg}^{-1}\right)$ & ECS_S & 0.066 & 0.003 & 0.024 & 0.017 & 73.7 \\
& ECS_SCM & 0.195 & 0.018 & 0.062 & 0.031 & 49.4 \\
& TS_S & 0.129 & 0.050 & 0.086 & 0.023 & 26.9 \\
$a_{\mathrm{ph}}^{*}(440) / a_{\mathrm{ph}}^{*}(675)$ & TS_SCM & 0.066 & 0.017 & 0.045 & 0.015 & 32.5 \\
& ECS_S & 0.158 & 0.030 & 0.074 & 0.023 & 31.8 \\
& ECS_SCM & 0.127 & 0.035 & 0.062 & 0.019 & 30.1 \\
$a_{\mathrm{ph}}^{*}(675)\left(\mathrm{m}^{2} \mathrm{mg}^{-1}\right)$ & TS_S & 0.035 & 0.015 & 0.024 & 0.005 & 19.9 \\
& TS_SCM & 0.028 & 0.008 & 0.021 & 0.006 & 28.0 \\
& ECS_S & 0.047 & 0.012 & 0.026 & 0.007 & 28.7 \\
& ECS_SCM & 0.055 & 0.016 & 0.027 & 0.008 & 29.6 \\
& TS_S & 4.75 & 2.94 & 3.57 & 0.48 & 13.6 \\
& TS_SCM & 2.56 & 1.83 & 2.19 & 0.19 & 8.8 \\
& ECS_S & 4.60 & 1.80 & 2.91 & 0.52 & 17.8 \\
& ECS_SCM & 2.82 & 1.83 & 2.32 & 0.18 & 7.9 \\
\hline & & & & & &
\end{tabular}

where $R^{2}$ and $N$ are the coefficient of determination and the number of samples, respectively. The power law functions in TS agreed well with those given by Bricaud et al. (1995), whereas most of ECS samples significantly diverged (Kolmogorov-Smirnov test, $P<0.01$ ) from the regressions of Bricaud et al. (1995), especially at high Tchl $a$.

\subsection{Variations of Tchl $a$-specific absorption coefficient}

The average $a_{\mathrm{ph}}^{*}(\lambda)$ in TS_S, TS_SCM, ECS_S and ECS_SCM displayed distinct differences in both their magnitude and spectrum shape (Table 1 and Fig. 2c). The largest differences in the magnitude of absorption were observed in the blue wavelength. The highest average $a_{\mathrm{ph}}^{*}(\lambda)$ in the blue region was observed in TS_S, and the lowest average $a_{\mathrm{ph}}^{*}(\lambda)$ and the flattest spectral shape was observed in TS_SCM. The average $a_{\mathrm{ph}}^{*}(\lambda)$ in ECS_S and ECS_SCM lay between the average values in TS_S and TS_SCM, and the average $a_{\mathrm{ph}}^{*}(\lambda)$ in ECS_S was higher than the value in ECS_SCM. The standard deviation of $a_{\mathrm{ph}}^{*}(440)$ indicated high variances in TS_S and ECS_S, lower variances in ECS_SCM, and the lowest variance in TS_SCM (Fig. 2c). In addition, $a_{\mathrm{ph}}^{*}(\lambda)$ in TS_S and ECS_S had distinct peaks around $490 \mathrm{~nm}$, probably ow- ing to the presence of the photoprotective pigment zeaxanthin (Barlow et al., 2002). $a_{\mathrm{ph}}^{*}(\lambda)$ of some samples from ECS_SCM exhibited a clear peak around $540 \mathrm{~nm}$, which possibly resulted from the absorption of phycoerythrin (Hoge et al., 1999; Ciotti et al., 2002). The presence of phycoerythrin makes it difficult to ideally separate particulate absorption into non-algal and algal components using methanol extraction technique (Mitchell et al., 2002).

Correlations of $a_{\mathrm{ph}}^{*}(\lambda)$ and Tchl $a$ were different between TS and ECS (Fig. 3c, d). Negative power correlations of Tchl $a$ with $a_{\mathrm{ph}}^{*}(440)\left(P<0.01, R^{2}=0.708\right)$ and with $a_{\mathrm{ph}}^{*}(675)$ $\left(P<0.01, R^{2}=0.287\right)$ were recorded in TS. The fitted power law functions for TS were close to those obtained by Bricaud et al. (1995) in the global ocean. However, in ECS, the power correlation between $a_{\mathrm{ph}}^{*}(440)$ and Tchl $a$ was poor $\left(P<0.01, R^{2}=0.094\right)$ and there was no significant power correlation between $a_{\mathrm{ph}}^{*}(675)$ and Tchl $a(P=0.84$, $R^{2}=0.000$ ).

Salinity of most ECS_S samples (60 out of 67) and half of ECS_SCM samples (25 out of 51) were <32 (range: 24.2 31.9, average: 30.2), indicating the influence of Changjiang River, while salinity in TS_S and TS_SCM was > 32 (range: 

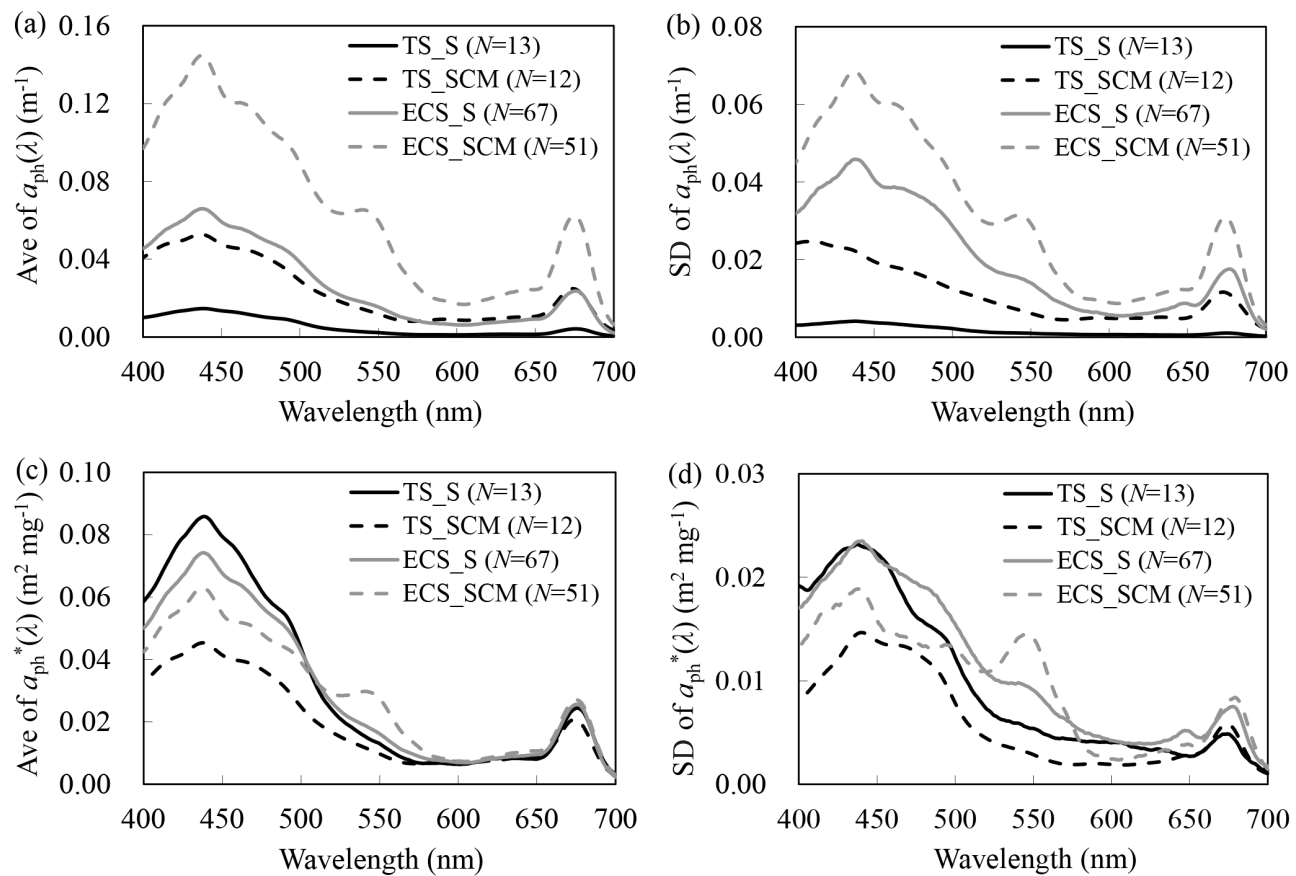

Fig. 2. Average (Ave) (a) and standard derivation (SD) (b) of $a_{\mathrm{ph}}(\lambda)$ and Ave (c) and SD (d) of $a_{\mathrm{ph}}^{*}(\lambda)$ in the Tsushima Strait surface (TS_S), Tsushima Strait SCM (TS_SCM), East China Sea surface (ECS_S), and East China Sea SCM (ECS_SCM).

32.2-34.3, average: 33.3). Although salinity of the other half of ECS_SCM samples (26 out of 51) was high (32.0-34.5), most of them (20 out of 26) were taken from waters just beneath the low-salinity waters. $a_{\mathrm{ph}}^{*}(440)$ and $a_{\mathrm{ph}}^{*}(675)$ of the high-salinity samples taken from TS as well as ECS were clustered around the regression lines of Bricaud et al. (1995) (Fig. 3). However, most of samples taken from ECS_S lowsalinity waters $(<32)$ and corresponding ECS_SCM samples taken from waters beneath them displayed higher $a_{\mathrm{ph}}^{*}(440)$ and $a_{\mathrm{ph}}^{*}(675)$ compared to the values from the regressions of Bricaud et al. (1995).

\subsection{Variations in the packaging effect and phytoplankton size classes estimated from HPLC pigment data}

The $Q_{\mathrm{a}}^{*}(440)$ showed similar variations as observed for $a_{\mathrm{ph}}^{*}(440)$ (Figs. 3c and 4a). The coefficient of determination $\left(R^{2}\right)$ of the linear regression between $a_{\mathrm{ph}}^{*}(440)$ and $Q_{\mathrm{a}}^{*}(440)$ were $0.869,0.978$ and 0.843 for both the locations, TS and ECS, respectively (data not shown). Consistent with $a_{\mathrm{ph}}^{*}(440)$, the highest and lowest average $Q_{\mathrm{a}}^{*}(440)$, with values of $0.72 \pm 0.17$ and $0.40 \pm 0.11$, were recorded in TS_S and TS_SCM, respectively. The average $Q_{\mathrm{a}}^{*}(440)$ in ECS_S and ECS_SCM were $0.64 \pm 0.19$ and $0.61 \pm 0.16$, respectively. Variations in $Q_{\mathrm{a}}^{*}(440)$ versus Tchl $a$ relationship were also clearly different between TS and ECS (Fig. 4a). $Q_{\mathrm{a}}^{*}(440)$ of surface and SCM waters from TS were inversely corre- lated with Tchl $a\left(P<0.01, R^{2}=0.704\right)$, but no correlation $\left(P=0.27, R^{2}=0.011\right)$ was found in ECS.

To confirm the effects of cell size on $Q_{\mathrm{a}}^{*}(440)$, we examined relationships between $Q_{\mathrm{a}}^{*}(440)$ and the size-fractions of micro-, nano- and pico-phytoplankton for all samples (Fig. 4b-d). $Q_{\mathrm{a}}^{*}(440)$ significantly decreased and increased with the increase in the micro- $\left(P<0.01, R^{2}=0.436\right)$ and pico-phytoplankton fractions $\left(P<0.01, R^{2}=0.309\right)$, respectively. There was no significant correlation between $Q_{\mathrm{a}}^{*}(440)$ and the nano-phytoplankton fraction $(P=0.02$, $\left.R^{2}=0.036\right)$. The average $Q_{\mathrm{a}}^{*}(440)$ of samples dominated by the micro-, nano- and pico-phytoplankton (fraction $>0.45$ ) were clearly different, with values of $0.46,0.64$, and 0.74 , respectively.

Phytoplankton size structure was different among TS_S, TS_SCM, ECS_S and ECS_SCM (Table 2 and Fig. 5), and generally agreed with $Q_{\mathrm{a}}^{*}(440)$ as discussed later. Pico- and micro-phytoplankton were dominant in TS_S and TS_SCM, respectively. Mixed populations of micro-, nano- and picophytoplankton were found in ECS_S, and abundant nanophytoplankton was seen in ECS_SCM. It was noticed that a fraction of pico-phytoplankton was still considerable in some samples at ECS_SCM (range: 0.02-0.51, average: 0.19). HPLC pigment data indicated that the pico-phytoplankton community in ECS and TS was made up of cyanobacteria. Variations in the phytoplankton size-fraction versus Tchl $a$ relationship were also different between TS and ECS (Fig. 6). In TS, micro-phytoplankton fraction increased as Tchl $a$ increased, while pico-phytoplankton fraction decreased with 

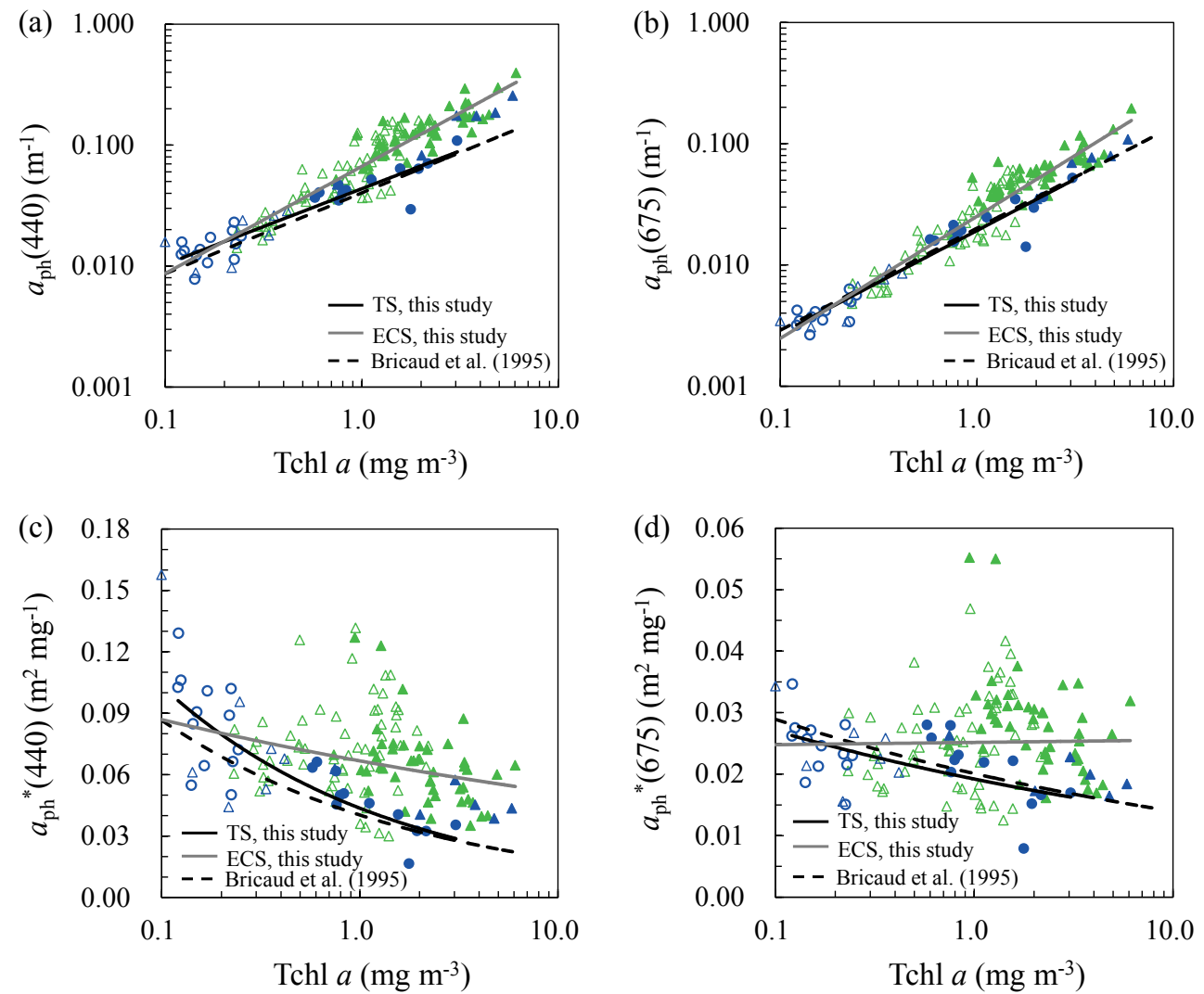

Fig. 3. Correlations between Tchl $a$ and $a_{\mathrm{ph}}(440)(\mathbf{a}), a_{\mathrm{ph}}(675)(\mathbf{b}), a_{\mathrm{ph}}^{*}(440)$ (c) and $a_{\mathrm{ph}}^{*}(675)$ (d) for samples from the Tsushima Strait surface (unfilled circle), Tsushima Strait SCM (filled circle), East China Sea surface (unfilled triangle), and East China Sea SCM (filled triangle). Green symbols indicate samples with a surface salinity $<32$, and blue symbols indicate samples with a surface salinity $>32$. Black and grey lines indicate power law functions fitted in the Tsushima Strait (TS) and East China Sea (ECS), respectively. Black dashes correspond to the regressions of Bricaud et al. (1995).

Table 2. Comparisons of Tchl $a$ size-fractions of micro-, nano- and pico-phytoplankton in the Tsushima Strait surface (TS_S), Tsushima Strait SCM (TS_SCM), East China Sea surface (ECS_S), and East China Sea SCM (ECS_SCM). Max: maximum; Min: minimum; Ave: average; SD: standard deviation; $\mathrm{CV}$ : coefficient of variation.

\begin{tabular}{lllllll}
\hline Location & Variable & Max & Min & Ave & SD & CV \\
\hline \multirow{3}{*}{ TS_S } & Micro & 0.42 & 0.00 & 0.14 & 0.16 & 117.9 \\
& Nano & 0.59 & 0.00 & 0.32 & 0.15 & 46.2 \\
\multirow{4}{*}{ TS_SCM } & Pico & 1.00 & 0.21 & 0.54 & 0.21 & 38.7 \\
& Micro & 0.85 & 0.23 & 0.58 & 0.21 & 36.6 \\
& Nano & 0.72 & 0.14 & 0.39 & 0.19 & 50.0 \\
ECS_S & Pico & 0.13 & 0.00 & 0.03 & 0.04 & 107.9 \\
& Micro & 0.75 & 0.00 & 0.26 & 0.20 & 76.7 \\
& Nano & 0.73 & 0.13 & 0.39 & 0.15 & 38.4 \\
ECS_SCM & Pico & 0.84 & 0.05 & 0.34 & 0.16 & 47.5 \\
& Micro & 0.80 & 0.09 & 0.32 & 0.15 & 46.7 \\
& Nano & 0.75 & 0.10 & 0.50 & 0.12 & 24.1 \\
& Pico & 0.51 & 0.02 & 0.19 & 0.11 & 59.1 \\
\hline
\end{tabular}



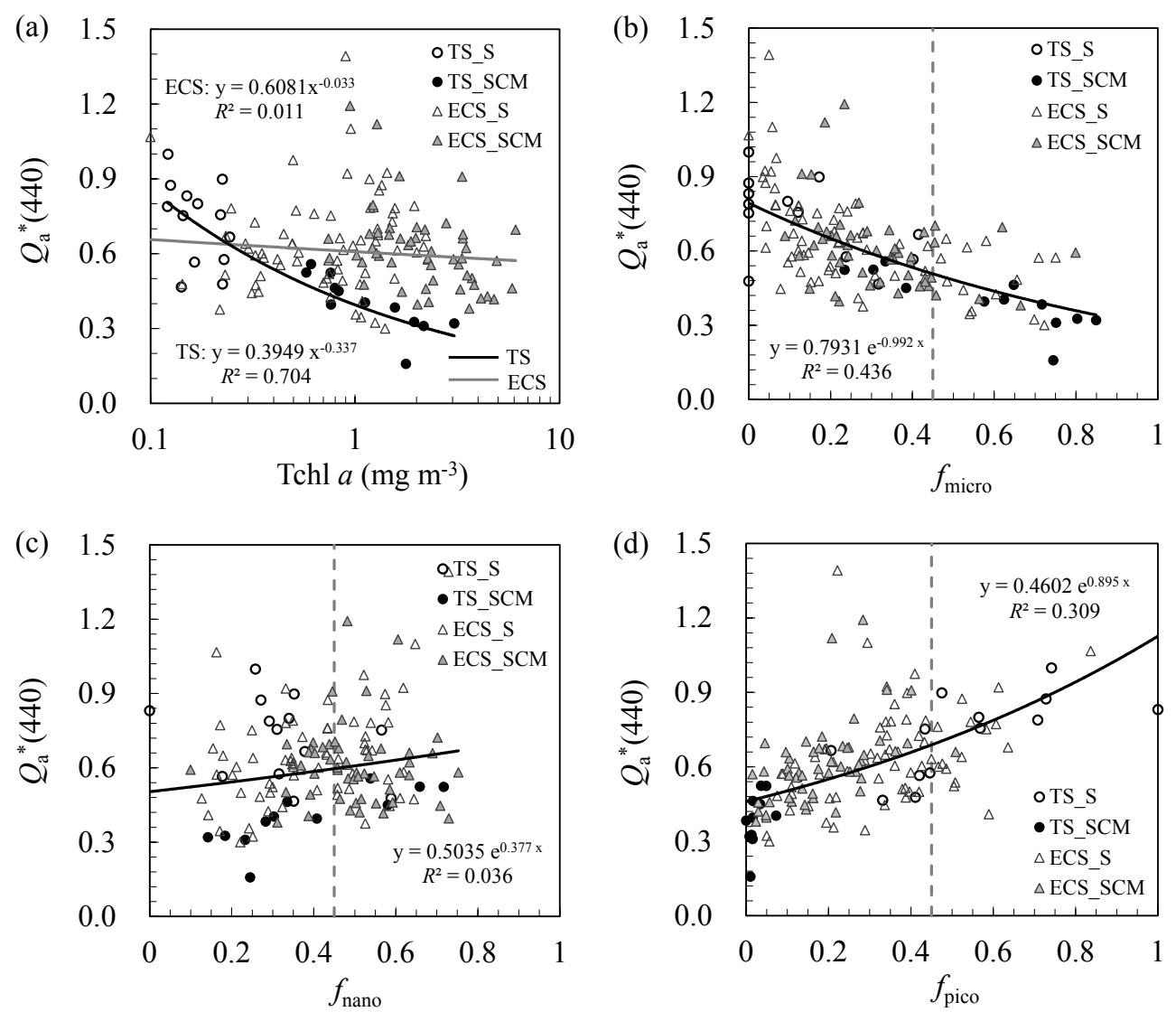

Fig. 4. Variations in $Q_{\mathrm{a}}^{*}(440)$ as a function of Tchl $a$ (a) and Tchl $a$ size-fractions of micro- (b), nano- (c), and pico-phytoplankton (d) for samples from the Tsushima Strait surface (TS_S), Tsushima Strait SCM (TS_SCM), East China Sea surface (ECS_S), and East China Sea SCM (ECS_SCM). In (a), black and grey lines indicate power law functions fitted in the Tsushima Strait (TS) and East China Sea (ECS). In Fig. 4 (b-d), black lines indicate exponential functions fitted from all samples, and grey vertical dashes are the boundaries of the dominant class with a fraction $>0.45$.
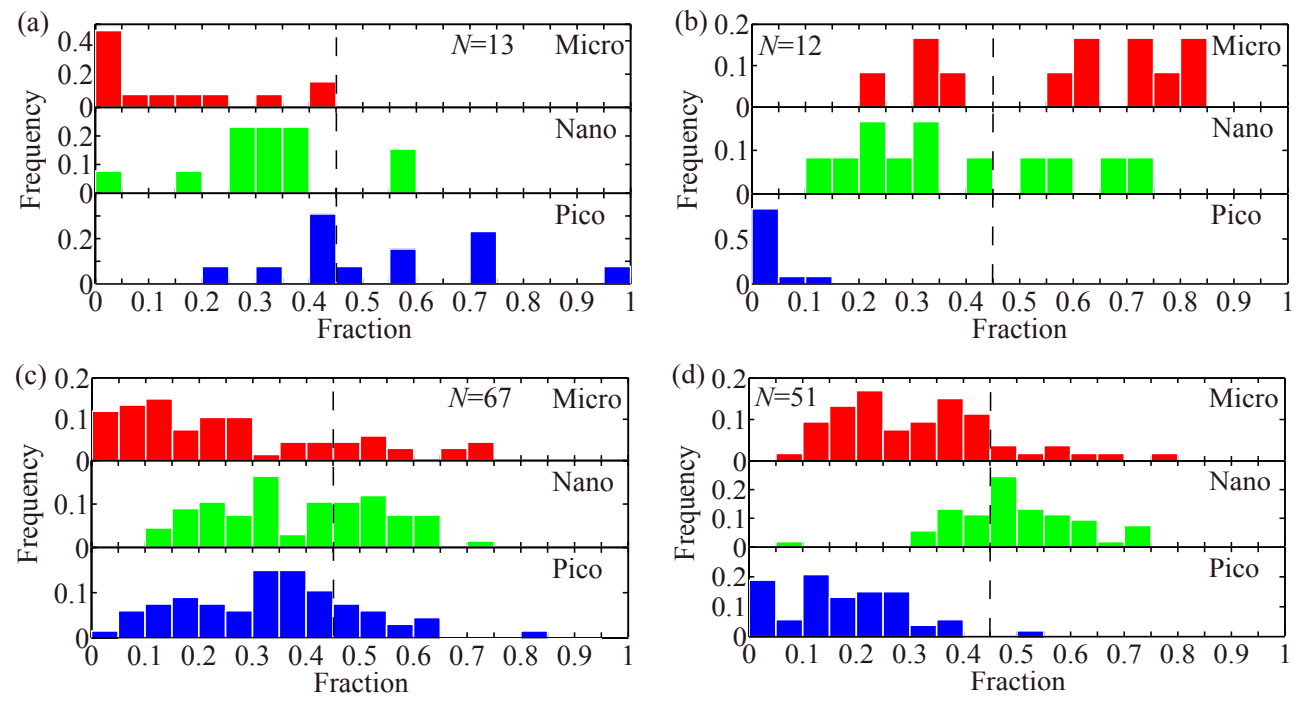

Fig. 5. Histograms showing the frequency distributions of Tchl $a$ size-fractions of micro-, nano- and pico-phytoplankton in the Tsushima Strait surface (a), Tsushima Strait SCM (b), East China Sea surface (c), and East China Sea SCM (d). Grey vertical lines are the boundaries of the dominant class with a fraction $>0.45$. 
increase in Tchl $a$, and nano-phytoplankton were abundant at medium Tchl $a$ levels. However, correlations between the size-fraction and Tchl $a$ in ECS were insignificant.

\subsection{Variations in phytoplankton pigment composition}

Based on Bricaud et al. (2004) phytoplankton accessory pigments measured in our study were classified into four groups: (1) photoprotective carotenoids (PPC); (2) photosynthetic carotenoids (PSC); (3) total Chl $b$ (Tchl $b$ ); and (4) total chlorophyll $c(\mathrm{Tchl} c)$ (detailed accessory pigments of each group described in Bricaud et al., 2004). The ratio of PPC to Tchl $a$ was higher in surface waters than in SCM waters both in TS and ECS (Fig. 7a). The ratio of PSC to Tchl $a$ had a relatively uniform distribution between the surface and SCM waters in ECS but there was a large difference in TS (Fig. 7b). The distribution of Tchl $b$ / Tchl $a$ ratio displayed no clear characteristics (Fig. 7c). Tchl $c /$ Tchl $a$ ratio was the lowest in TS_S and the highest in TS_SCM, and it was similar between ECS_S and ECS_SCM (Fig. 7d).

The diversity of pigment composition caused small but significant variations in $a_{\mathrm{pigm}}^{*}$ (440) (Fig. 8). The linear regression analysis between $a_{\mathrm{ph}}^{*}(440)$ and $a_{\mathrm{pigm}}^{*}(440)$ in all samples indicated that $35.1 \%$ of the variation in $a_{\mathrm{ph}}^{*}(440)$ could be explained by $a_{\text {pigm }}^{*}$ (440) (Fig. 8a). The corresponding contributions for TS and ECS were $45.7 \%$ and $39.1 \%$, respectively. In addition, $a_{\text {pigm }}^{*}(440)$ had a weak power correlation with Tchl $a\left(P=0.02, R^{2}=0.218\right)$ in TS, and a poor correlation in ECS $\left(P=0.04, R^{2}=0.037\right)$ (Fig. 8b). Values of $a_{\text {pigm }}^{*}(440)$ were similar in ECS_S and TS_S with averages and standard deviations of $0.060 \pm 0.008 \mathrm{~m}^{2} \mathrm{mg}^{-1}$ and $0.064 \pm 0.007 \mathrm{~m}^{2} \mathrm{mg}^{-1}$, respectively. The values were also similar in ECS_SCM $\left(0.054 \pm 0.004 \mathrm{~m}^{2} \mathrm{mg}^{-1}\right)$ and TS_SCM $\left(0.060 \pm 0.004 \mathrm{~m}^{2} \mathrm{mg}^{-1}\right)$.

The variability in $a_{\text {pigm }}^{*}(675)$ was smaller than that in $a_{\text {pigm }}^{*}(440)$ (data not shown). A linear regression analysis between $a_{\mathrm{ph}}^{*}(675)$ and $a_{\mathrm{pigm}}^{*}(675)$ revealed that the pigment composition was responsible for only $13.2 \%$ of the variation in $a_{\mathrm{ph}}^{*}(675)$, which confirmed that the main variation of $a_{\mathrm{ph}}^{*}(\lambda)$ was originated from the packaging effect.

\section{Discussion}

\subsection{General factors influencing phytoplankton light absorption}

The packaging effect and pigment composition are the two main causes of the variations in $a_{\mathrm{ph}}^{*}(\lambda)$ (Morel and Bricaud, 1981; Bricaud et al., 1995). Of the two factors, the packaging effect is the dominant one (Morel and Bricaud, 1981; Stuart et al., 1998). Our results of a high correlation between $a_{\mathrm{ph}}^{*}(440)$ and $Q_{\mathrm{a}}^{*}(440)$ confirms that is true for ECS and TS as well. Linear regression analyses between $a_{\text {pigm }}^{*}(\lambda)$ and $a_{\mathrm{ph}}^{*}(\lambda)$ at both $440 \mathrm{~nm}$ and $675 \mathrm{~nm}$ also indicated the dominance of the packaging effect in causing variability in $a_{\mathrm{ph}}^{*}(\lambda)$ (Fig. 8a). These results are in agreement with those of Stuart et al. (1998) who also used a multiple regression analysis between $a_{\mathrm{ph}}^{*}(440)$ and the concentrations of all the major pigments normalized to $\mathrm{Chl} a$, and suggested that $58 \%$ to $71 \%$ of variability in $a_{\mathrm{ph}}^{*}(440)$ could be explained by the packaging effect.

The packaging effect in turn is significantly influenced by phytoplankton cell size (Morel and Bricaud, 1981; Ciotti et al., 2002; Zhang et al., 2012). It is well known that large phytoplankton produce a strong packaging effect, which results in low $a_{\mathrm{ph}}^{*}(\lambda)$, while $a_{\mathrm{ph}}^{*}(\lambda)$ of small phytoplankton is high because of the lower packaging effect (Stuart et al., 1998; Babin et al., 2003). In this study, we found that the packaging effect increased and decreased with abundance of micro- and pico-phytoplankton, respectively (Fig. 4b-d). These findings are generally consistent with those of Costa Goela et al. (2013) who reported that the packaging effect represented by $a_{\mathrm{ph}}(440) / a_{\mathrm{ph}}(678)$ ratio was negatively correlated with the micro-phytoplankton fraction and positively correlated with the nano- and pico-phytoplankton fractions.

Note that the intracellular pigment concentration, which usually changes with light conditions due to photoacclimation, also affects $a_{\mathrm{ph}}^{*}(\lambda)$ through the packaging effect in the same way as cell size (Morel and Bricaud, 1981). As reported by Lohrenz et al. (2003), because of the high intracellular pigment concentration, the packaging effect was evident even when the cell size was $<3 \mu \mathrm{m}$ for SCM samples from west Florida. The data set collected in this study incorporated SCM samples from TS and ECS, which might possess high intracellular pigment concentrations as an adaption to the low irradiance conditions. Even in surface waters, the intracellular pigment concentration is variable due to changes in light conditions (Bricaud et al., 2004). Therefore, although phytoplankton cell size was a key factor controlling $a_{\mathrm{ph}}^{*}(\lambda)$ through the packaging effect in this study, the intracellular pigment concentration may be another factor causing variations in $a_{\mathrm{ph}}^{*}(\lambda)$.

\subsection{Correlations among Tchl $a$, phytoplankton size-fraction, and $a_{\mathrm{ph}}^{*}(\lambda)$ in ECS and TS}

For the global ocean, micro-phytoplankton are abundant in high-Chl $a$ waters and their fraction increases with an increase in Chl $a$. In contrast, pico-phytoplankton prevail in low-Chl $a$ waters and their fraction decreases with an increase in Chl $a$, while nano-phytoplankton dominate in medium-Chl $a$ waters (Kameda and Ishizaka, 2005; Brewin et al., 2010). In TS, variations in the phytoplankton size-fraction were similar to those reported by Brewin et al. (2010) (Fig. 6a), suggesting that phytoplankton in TS possess the typical characteristics of those in the global ocean. These observations also imply that the size-based twoor three-population absorption models (Sathyendranath et 

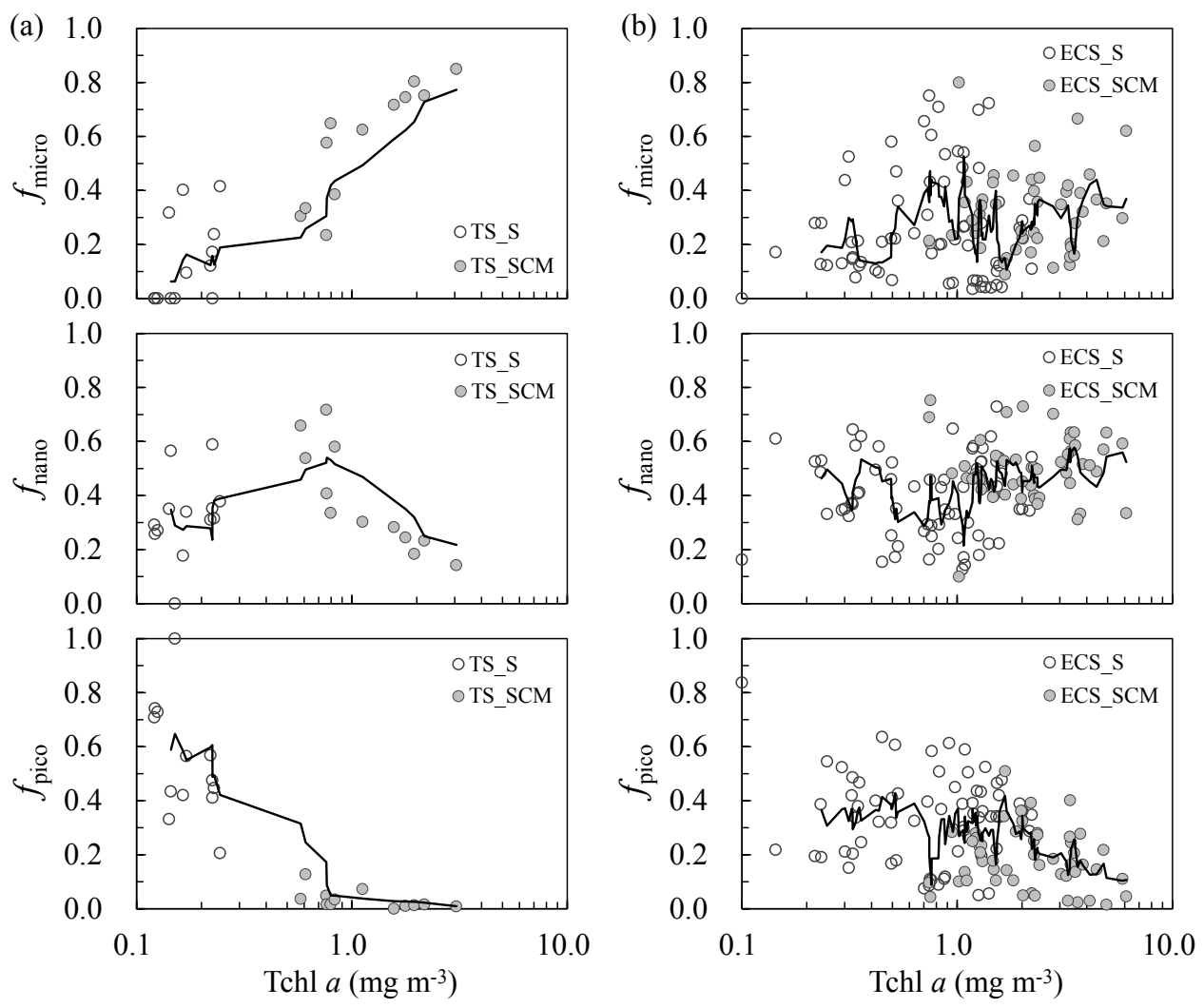

Fig. 6. Variations in Tchl $a$ size-fractions of micro-, nano- and pico-phytoplankton as a function of Tchl $a$ in the Tsushima Strait (TS) (a) and East China Sea (ECS) (b). TS_S, TS_SCM, ECS_S and ECS_SCM represent the Tsushima Strait surface, Tsushima Strait SCM, East China Sea surface, and East China Sea SCM, respectively. Lines represent the five-point running average.

al., 2001; Devred et al., 2006, 2011; Brewin et al., 2011) and the size-fraction estimation models (Uitz et al., 2006; Brewin et al., 2010; Hirata et al., 2011), which were proposed based on the correlations of size-fraction with Chl $a$ in the global ocean, could be applicable in TS. However, in ECS no clear trends were noted in the relationship between phytoplankton cell size and Tchl $a$ (Fig. 6b). When we applied the model of Hirata et al. (2011) in ECS, the relative RMSEs between model-retrieved and HPLC-estimated fractions were $338.0 \%, 66.9 \%$ and $103.8 \%$ for micro-, nanoand pico-phytoplankton, respectively. At high Tchl $a$ range, the model-retrieved fractions overestimated (underestimated) for micro-phytoplankton (pico-phytoplankton). These findings indicate that the models mentioned above are not applicable in ECS.

In general, $a_{\mathrm{ph}}^{*}(\lambda)$ was negatively correlated with Chl $a$ in the global ocean, and these correlations were stable even when subsurface samples were incorporated (Bricaud et al., 1995). In our study, consistent negative correlations between $a_{\mathrm{ph}}^{*}(\lambda)$ and Tchl $a$ with those of Bricaud et al. (1995) were observed in TS, but not in ECS (Fig. 3c, d). The factors responsible for these differences between TS and ECS were summarized in Fig. 9. From Fig. 9, it can be seen that, in
TS, $Q_{\mathrm{a}}^{*}(440)$, which played a leading role in determining $a_{\mathrm{ph}}^{*}(440)$, was strongly correlated with Tchl $a(P<0.01$, $\left.R^{2}=0.704\right)$, whereas $a_{\text {pigm }}^{*}(440)$ had a weak correlation with Tchl $a\left(P=0.02, R^{2}=0.218\right)$. This implies that the significant correlation for $a_{\mathrm{ph}}^{*}(440)$ with Tchl $a(P<0.01$, $\left.R^{2}=0.708\right)$ was mainly driven by $Q_{\mathrm{a}}^{*}(440)$. The significant correlation between $Q_{\mathrm{a}}^{*}(440)$ and Tchl $a$ was primarily controlled by the cell size variations by the fact that picophytoplankton with a large $Q_{\mathrm{a}}^{*}(440)$ dominated at low Tchl $a$, nano-phytoplankton with moderate $Q_{\mathrm{a}}^{*}(440)$ at medium Tchl $a$, and micro-phytoplankton with small $Q_{\mathrm{a}}^{*}(440)$ at high Tchl $a$. However, in ECS, the phytoplankton size-fractions displayed irregular trends, which resulted in a poor correlation between $Q_{\mathrm{a}}^{*}(440)$ and Tchl $a\left(P=0.27, R^{2}=0.011\right)$. $a_{\text {pigm }}^{*}(440)$ was also not correlated with Tchl $a(P=0.04$, $\left.R^{2}=0.037\right)$. Due to the influence of these factors, $a_{\mathrm{ph}}^{*}(440)$ was poorly correlated with Tchl $a\left(P<0.01, R^{2}=0.094\right)$ (Fig. 9).

Babin et al. (2003) observed that some coastal samples significantly departed from the general relationships between $a_{\mathrm{ph}}(\lambda)$ and Chl $a$ established in the global ocean by Bricaud et al. (1995), though most data merged from all of the coastal 

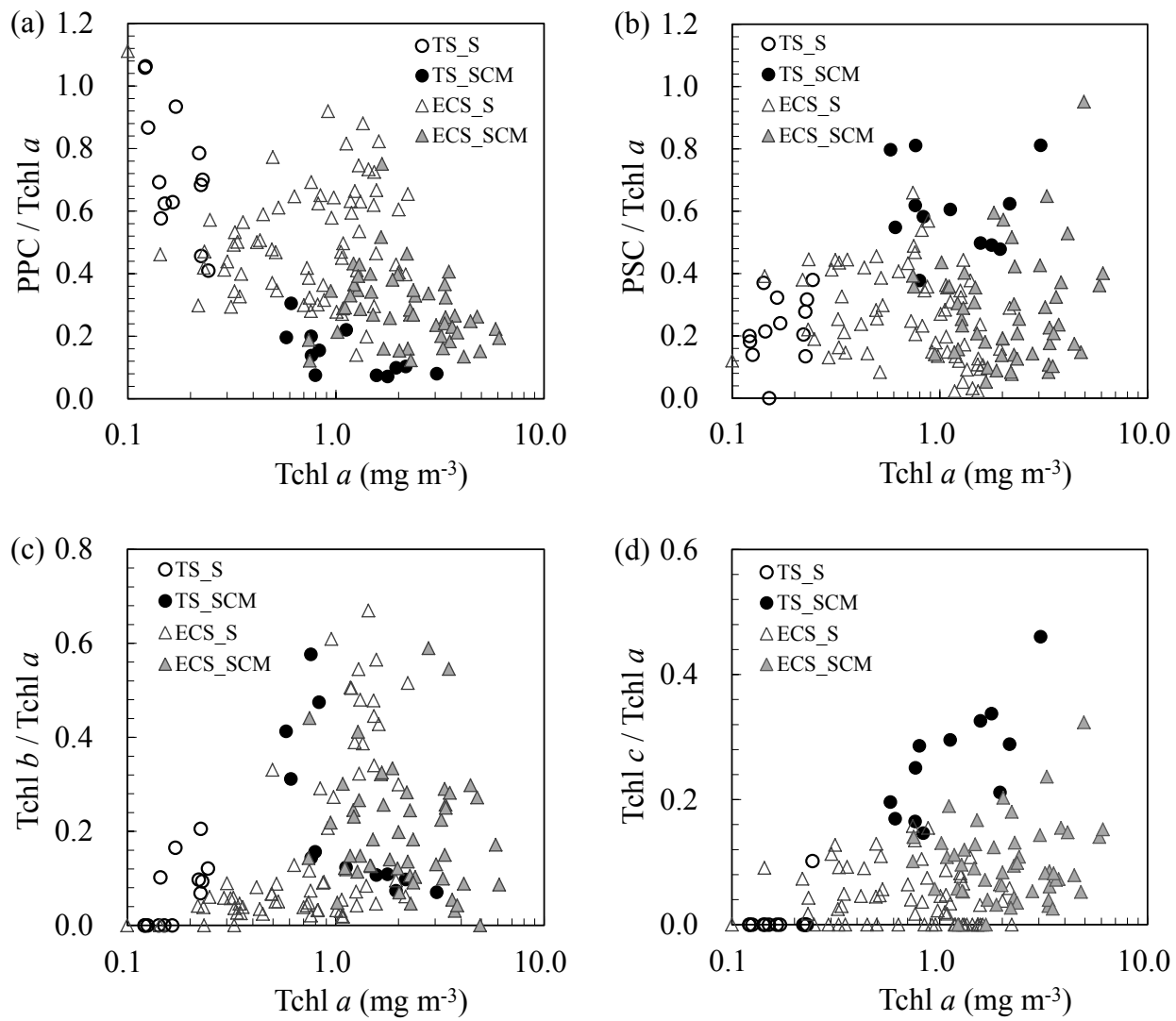

Fig. 7. Variations in the ratios of PPC (a), PSC (b), Tchl $b$ (c), and Tchl $c$ (d) to Tchl $a$ as a function of Tchl $a$ in the Tsushima Strait surface (TS_S), Tsushima Strait SCM (TS_SCM), East China Sea surface (ECS_S) and East China Sea SCM (ECS_SCM).
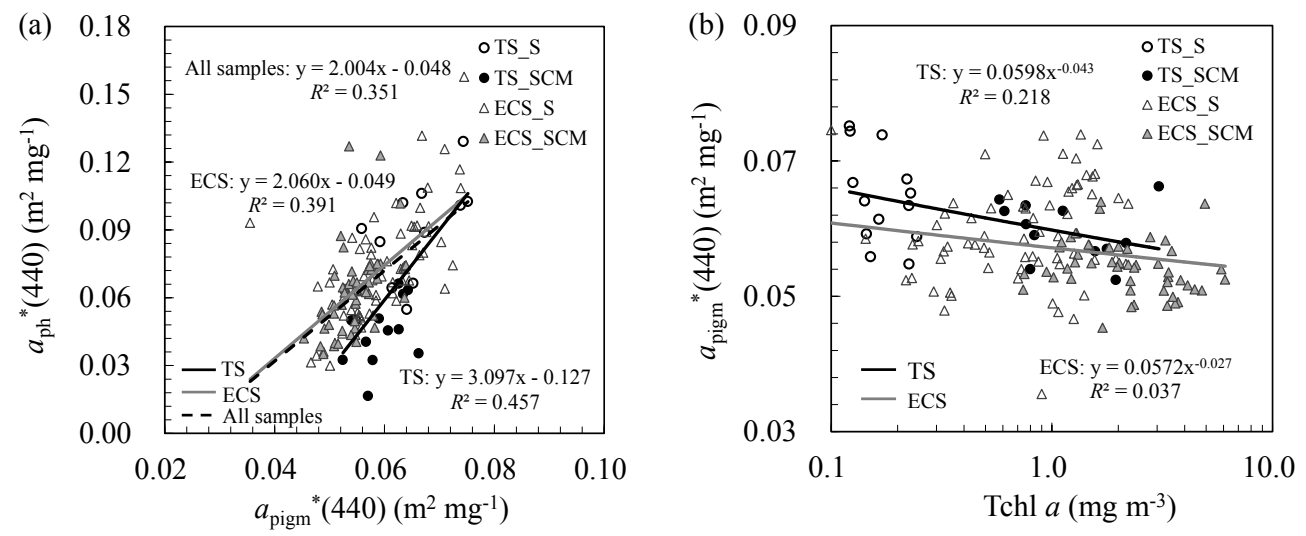

Fig. 8. Variations of $a_{\mathrm{pigm}}^{*}(440)$ versus $a_{\mathrm{ph}}^{*}(440)$ (a) and Tchl $a$ (b) in the Tsushima Strait surface (TS_S), Tsushima Strait SCM (TS_SCM), East China Sea surface (ECS_S), and East China Sea SCM (ECS_SCM). Solid black and grey lines indicate linear regressions in the Tsushima Strait (TS) and East China Sea (ECS), respectively. Dashed black line is the linear regression for all samples.

regions displayed a similar tendency to that of Bricaud et al. (1995). In the case of $\operatorname{ECS} a_{\mathrm{ph}}^{*}(\lambda)$ was poorly correlated with Tchl $a$, and most of samples showed higher values in $a_{\mathrm{ph}}^{*}(\lambda)$ than those in TS and from the global regressions at high Tchl $a$ (Fig. 3c, d). Note that ECS samples that deviated from the regressions of Bricaud et al. (1995) were mainly taken from the surface low-salinity waters $(<32)$ and SCM waters beneath them, suggesting that the distinct properties in ECS are possibly influenced by the Changjiang freshwater. These findings imply that specific parameterisations of 

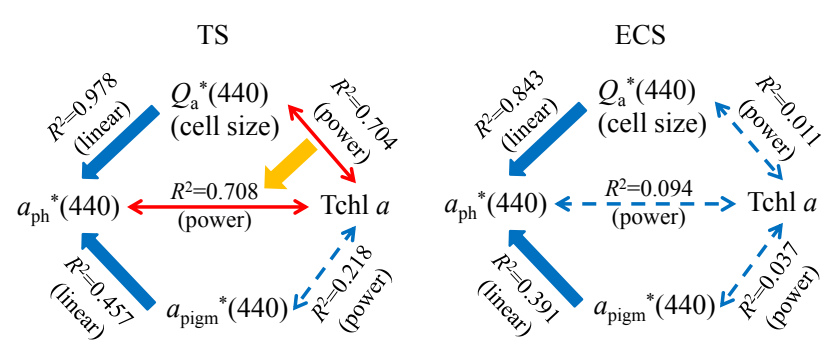

Fig. 9. Summary of the relationships among $a_{\mathrm{ph}}^{*}(440), Q_{\mathrm{a}}^{*}(440)$, $a_{\text {pigm }}^{*}(440)$, and Tchl $a$ in the Tsushima Strait (TS) and East China Sea (ECS).

the correlation between $a_{\mathrm{ph}}^{*}(\lambda)$ and $\mathrm{Chl} a$ that are true for the global ocean may not necessarily be valid for coastal regions, in particular those that come under the influence of river discharge.

\subsection{Differences of phytoplankton absorption and its influencing factors between ECS and TS}

Our results revealed a clear difference in salinity and the phytoplankton bio-optical properties between ECS_S and TS_S. The low salinity $(<32)$ in ECS_S and the high salinity ( $>$ 32) in TS_S confirmed the strong and weak influence of the Changjiang freshwater on ECS_S and TS_S, respectively (Fig. 3). The lower salinity and higher Tchl $a$ in ECS_S than in TS_S (Table 1) agreed with the results of Yamaguchi et al. (2012) who suggested that $\mathrm{Chl} a$ was enhanced by CDW in ECS_S. As a consequence of higher Tchl $a$, higher $a_{\mathrm{ph}}(\lambda)$ were observed in ECS_S than in TS_S (Figs. 2a and 3a, b). However, on average $a_{\mathrm{ph}}^{*}(\lambda)$ in ECS_S was lower than in TS_S (Table 1 and Fig. 2c). Comparisons of the packaging effect and $a_{\text {pigm }}^{*}(440)$ which showed a lower $Q_{a}^{*}(440)$ in ECS_S than in TS_S and similar $a_{\text {pigm }}^{*}(440)$ between ECS_S and TS_S (Figs. 4a and 8), suggest that the lower $a_{\mathrm{ph}}^{*}(\lambda)$ in ECS_S than TS_S was primarily caused by the stronger packaging effect in ECS_S. The phytoplankton size structure revealed that the stronger packaging effect in ECS_S was caused by abundant large phytoplankton (Figs. 5 and 6 ).

It should be noted that, though $a_{\mathrm{ph}}^{*}(\lambda)$ was generally lower in ECS_S than in TS_S, $a_{\mathrm{ph}}^{*}(\lambda)$ of the majority of low-salinity waters in ECS_S were higher than the values from the regressions of Bricaud et al. (1995) (Fig. 3c, d). From Fig. 6b, it can be seen that pico-phytoplankton represented by cyanobacteria were still abundant in ECS_S, even though Tchl $a$ was high. This result contradicts previous observations that large phytoplankton was abundant in high-Chl $a$ waters (Brewin et al., 2010; Hirata et al., 2011), and indicated that the abundance of pico-phytoplankton was responsible for the higher $a_{\mathrm{ph}}^{*}(\lambda)$ in ECS_S than the values from the regressions of Bricaud et al. (1995).

Within the SCM, salinity of values of some samples showed freshwater influences (28.8-31.9), and salinity of some samples were high (33.4-34.3). However, most of the high-salinity samples were taken from waters beneath ECS_S low-salinity waters. These imply that ECS_SCM waters were also influenced by the Changjiang freshwater to some extent. The average Tchl $a$ of ECS_SCM was nearly twice as high as that of TS_SCM, and the average $a_{\mathrm{ph}}(\lambda)$ of ECS_SCM was almost three times larger than that of TS_SCM (Table 1). As a result, $a_{\mathrm{ph}}^{*}(\lambda)$ was much higher in ECS_SCM than in TS_SCM (Figs. 2c and 3c, d). By comparing the packaging effect (cell size) and $a_{\text {pigm }}^{*}(440)$, we found that the packaging effect (cell size) was the main cause for the differences in $a_{\mathrm{ph}}^{*}(\lambda)$ between ECS_SCM and TS_SCM (Figs. 4a and 8). In TS_SCM, fractions of pico-phytoplankton were low, and micro-phytoplankton became dominant class (Figs. 5b and 6a). However, in ECS_SCM an abundant nano-phytoplankton and considerable pico-phytoplankton were observed, and fractions of micro-phytoplankton were not high (Figs. $5 \mathrm{~d}$ and $6 \mathrm{~b}$ ). Eventually, the smaller cells might generate higher $a_{\mathrm{ph}}^{*}(\lambda)$ in ECS_SCM than in TS_SCM. In addition, as with ECS_S low-salinity waters, $a_{\mathrm{ph}}^{*}(\lambda)$ of most ECS_SCM waters beneath ECS_S low-salinity waters was also higher than the values of the regression of Bricaud et al. (1995) (Fig. 3c, d). This was attributable to the abundant nano-phytoplankton and considerable pico-phytoplankton in ECS_SCM (Figs. 5d and $6 \mathrm{~b})$.

\subsection{Potential influences of the Changjiang discharge on ECS}

As discussed in Sect. 4.2 and 4.3, distinct phytoplankton absorption characteristics generally distributed in the surface low-salinity waters and SCM waters just beneath them in ECS, and size structure was the main factor responsible for the distinct absorption. It is well known that phytoplankton size structure is related to local nutrient availability. Oligotrophic and eutrophic waters are dominated by small and large phytoplankton, respectively (Stæhr et al., 2004; Uitz et al., 2008). Consistently, abundant picophytoplankton were seen in oligotrophic waters of TS_S, and micro-phytoplankton dominated in TS_SCM where the nutrients were abundant (unpublished data). For ECS, large amounts of nitrogen were supplied by the Changjiang to the shelf area during summer (Gong et al., 1996). As a response of phytoplankton community to the available nutrients, diatoms were reported to be the dominant group in high Chl $a$ waters in the Changjiang estuary and adjacent area in summer (Zhou et al., 2008; Li et al., 2009; Zhu et al., 2009). CDW takes about 1 month to reach the mid-shelf region (Yamaguchi et al., 2012). During the 1 month extension of CDW, there may be significant changes in the phytoplankton community. Similar to our study, a mixed structure of micro-, nano- and pico-phytoplankton was observed in ECS_S and nano-phytoplankton dominated in ECS_SCM (Fig. 5c, d). 
It may be noted that Tchl $a$ was still high at both surface and SCM in the mid-shelf region of ECS; however, at such Tchl $a$ levels, the fraction of micro-phytoplankton was lower, while the fractions of pico- and/or nano-phytoplankton were higher than those in TS and those reported for the global ocean (Fig. 6). This phenomenon may be related to the nutrient structure. Previous studies have shown that the Changjiang discharge can significantly alter nutrient conditions in ECS causing high N/P ratios in ECS_S and ECS_SCM, particularly in the western part of ECS_S (unpublished data; Wang et al., 2003; Zhang et al., 2007). Over the past decades, a decreasing trend in the relative abundance of diatoms and an increasing trend of dinoflagellates in the Changjiang estuary and adjacent area were reported, which were attributed to increasing N/P ratios (Zhou et al., 2008). This observation was confirmed by Li et al. (2009). In other regions, changes of phytoplankton community due to nutrient structure have also been reported. Shen (2001) suggested that the changes in nutrient structure (increase in N/P ratio and decrease in $\mathrm{Si} / \mathrm{P}$ and $\mathrm{Si} / \mathrm{N}$ ratios) may have led to a shift from large cells to small cells in Jiaozhou Bay. In the Bay of Biscay, N/P ratios were high in late winter and spring due to the river discharge, and waters were predominated by small phytoplankton $(<3 \mu \mathrm{m}$, fraction ranged from 0.4 to 0.7$)$, due to the limitation of phosphorus (Herbland et al. 1998). On the basis of these earlier reports, we speculate that the high $\mathrm{N} / \mathrm{P}$ ratios might be an important factor that causes a decrease in micro-phytoplankton fraction and corresponding increases in nano- and/or pico-phytoplankton fractions in the mid-shelf region of ECS.

We also do not rule out that other factors could have an influence on the structure of phytoplankton communities of ECS (Jiao et al., 2002, 2005; Zhu et al., 2009). As suggested by Jiao et al. (2002, 2005), light and temperature were also controlling factors for Synechococcus in CDW (Jiao et al., 2002, 2005). Further investigations therefore are required to clarify the controlling factors of the phytoplankton community in mid-shelf region of ECS which is influenced by Changjiang freshwater.

\section{Conclusions}

We confirmed that the packaging effect was the predominant cause of variations in $a_{\mathrm{ph}}^{*}(\lambda)$, and it significantly increased and decreased with increase in micro- and picophytoplankton fractions, respectively. More importantly, we were able to observe clear differences in phytoplankton size structure and therefore absorption properties between TS and ECS possibly attributable to the Changjiang discharge.

In the low-salinity surface waters of ECS which were indicative of the influence of Changjiang freshwater on ECS, mixed populations of micro-, nano- and pico-phytoplankton were found. In contrast, pico-phytoplankton dominated in surface waters of TS. Consequently, on average $a_{\mathrm{ph}}^{*}(\lambda)$ in
ECS was lower than TS. Within SCM, average $a_{\mathrm{ph}}^{*}(\lambda)$ was higher in ECS than in TS because of the dominance of the nano-phytoplankton community in ECS while microphytoplankton dominated in TS.

By pooling surface and SCM samples, phytoplankton in TS displayed a well-ordered trend in size-fraction versus Tchl $a$; and correlations between $a_{\mathrm{ph}}^{*}(\lambda)$ and Tchl $a$ consistent with previous observations for the global ocean. However, these patterns and correlations broke down in waters of ECS. At high Tchl $a$ levels, most samples collected from the surface low-salinity waters and SCM waters beneath them showed higher values of $a_{\mathrm{ph}}^{*}(\lambda)$ than those in TS and derived from the global regressions between $a_{\mathrm{ph}}^{*}(\lambda)$ and Tchl $a$. The observed higher $a_{\mathrm{ph}}^{*}(\lambda)$ was attributed to the presence of distinct phytoplankton size structure in ECS, where nanoand/or pico-phytoplankton fractions were higher and microphytoplankton fraction was lower at high Tchl $a$ level than those in TS and expected for the global ocean. Changes in nutrient structure by the Changjiang discharge may be an important factor explaining the distinct phytoplankton size structure in ECS. Further investigations are required to reestablish this proposition.

Overall, our observations indicate that the correlations between Tchl $a$ with phytoplankton size-fraction as well as $a_{\mathrm{ph}}^{*}(\lambda)$ reported in the global ocean, are not valid for ECS possibly due to the influence of Changjiang discharge. These findings imply that general bio-optical models coupling the relationships between Tchl $a$ with phytoplankton size-fraction or $a_{\mathrm{ph}}^{*}(\lambda)$ are not applicable in ECS, and more attention should be given when applying the general biooptical models in regions influenced by riverine discharge.

Acknowledgements. We would like to thank the captains, officers and crews of T/V Nagasaki maru and R/V Tansei maru for excellent assistance during field sampling and measurements. We also appreciate four anonymous reviewers for the constructive comments towards improving this manuscript. This research was partly supported by the Second-generation Global Imager project of the Japan Aerospace Exploration Agency.

Edited by: K. Suzuki

\section{References}

Babin, M., Therriault, J. C., Legendre, L., and Condal, A.: Variations in the specific absorption coefficient for natural phytoplankton assemblages: Impact on estimates of primary production, Limnol. Oceanogr., 38, 154-177, 1993.

Babin, M., Stramski, D., Ferrari, G. M., Claustre, H., Bricaud, A., Obolensky, G., and Hoepffner, N.: Variations in the light absorption coefficients of phytoplankton, nonalgal particles, and dissolved organic matter in coastal waters around Europe, J. Geophys. Res., 108, 3211, doi:10.1029/2001jc000882, 2003. 
Bannister, T. T.: A general theory of steady state phytoplankton growth in a nutrient saturated mixed layer, Limnol. Oceanogr., 19, 13-30, 1974.

Barlow, R. G., Aiken, J., Holligan, P. M., Cummings, D. G., Maritorena, S., and Hooker, S.: Phytoplankton pigment and absorption characteristics along meridional transects in the Atlantic Ocean, Deep-Sea Res. Pt. I, 49, 637-660, 2002.

Brewin, R. J. W., Sathyendranath, S., Hirata, T., Lavender, S. J., Barciela, R. M., and Hardman-Mountford, N. J.: A threecomponent model of phytoplankton size class for the Atlantic Ocean, Ecol. Model., 221, 1472-1483, 2010.

Brewin, R. J. W., Devred, E., Sathyendranath, S., Lavender, S. J., and Hardman-Mountford, N. J.: Model of phytoplankton absorption based on three size classes, Appl. Optics, 50, 4535-4549, 2011.

Bricaud, A., Babin, M., Morel, A., and Claustre, H.: Variability in the chlorophyll-specific absorption coefficients of natural phytoplankton: Analysis and parameterization, J. Geophys. Res., 100, 13321-13332, 1995.

Bricaud, A., Claustre, H., Ras, J., and Oubelkheir, K.: Natural variability of phytoplanktonic absorption in oceanic waters: Influence of the size structure of algal populations, J. Geophys. Res., 109, C11010, doi:10.1029/2004jc002419, 2004.

Brunelle, C. B., Larouche, P., and Gosselin, M.: Variability of phytoplankton light absorption in Canadian Arctic seas, J. Geophys. Res., 117, C00G17, doi:10.1029/2011jc007345, 2012.

Ciotti, A. M., Lewis, M. R., and Cullen, J. J.: Assessment of the relationships between dominant cell size in natural phytoplankton communities and the spectral shape of the absorption coefficient, Limnol. Oceanogr., 47, 404-417, 2002.

Ciotti, A. M. and Bricaud, A.: Retrievals of a size parameter for phytoplankton and spectral light absorption by colored detrital matter from water-leaving radiances at SeaWiFS channels in a continental shelf region off Brazil, Limnol. Oceanogr.-Meth., 4, 237-253, 2006.

Cleveland, J. S., and Weidemann, A. D.: Quantifying Absorption by Aquatic Particles: A Multiple Scattering Correction for GlassFiber Filters, Limnol. Oceanogr., 38, 1321-1327, 1993.

Cleveland, J. S.: Regional models for phytoplankton absorption as a function of chlorophyll $a$ concentration, J. Geophys. Res., 100, 13333-13344, 1995.

Costa Goela, P., Icely, J., Cristina, S., Newton, A., Moore, G., and Cordeiro, C.: Specific absorption coefficient of phytoplankton off the Southwest coast of the Iberian Peninsula: A contribution to algorithm development for ocean colour remote sensing, Cont. Shelf Res., 52, 119-132, doi:10.1016/j.csr.2012.11.009, 2013.

D'Sa, E. J., Miller, R. L., and Del Castillo, C.: Bio-optical properties and ocean color algorithms for coastal waters influenced by the Mississippi River during a cold front. Appl. Optics, 45, 74107428, 2006.

Devred, E., Sathyendranath, S., Stuart, V., Maass, H., Ulloa, O., and Platt, T.: A two-component model of phytoplankton absorption in the open ocean: Theory and applications, J. Geophys. Res., 111, C03011, doi:10.1029/2005JC002880, 2006.

Devred, E., Sathyendranath, S., Stuart, V., and Platt, T.: A three component classification of phytoplankton absorption spectra: Application to ocean-color data, Remote Sens. Environ., 115, 2255-2266, 2011.
Garver, S. A., and Siegel, D. A.: Inherent optical property inversion of ocean color spectra and its biogeochemical interpretation 1. Time series from the Sargasso Sea, J. Geophys. Res., 102, 18607-18625, 1997.

Gong, G. C., Lee Chen, Y. L., and Liu, K. K.: Chemical hydrography and chlorophyll $a$ distribution in the East China Sea in summer: implications in nutrient dynamics, Cont. Shelf Res., 16, 1561-1590, 1996.

Gordon, H. R., Brown, O. B., Evans, R. H., Brown, J. W., Smith, R. C., Baker, K. S., and Clark, D. K.: A semianalytic radiance model of ocean color, J. Geophys. Res., 93, 10909-10924, 1988.

Guo, X., Miyazawa, Y., and Yamagata, T.: The Kuroshio onshore intrusion along the shelf break of the East China Sea: the origin of the Tsushima Warm Current, J. Phys. Oceanogr., 36, 22052231, 2006.

Hama, T., Shin, K., and Handa, N.: Spatial variability in the primary productivity in the East China Sea and its adjacent waters, J. Oceanogr., 53, 41-51, 1997.

Harimoto, T., Ishizaka, J., and Tsuda, R.: Latitudinal and vertical distributions of phytoplankton absorption spectra in the central North Pacific during spring 1994, J. Oceanogr., 55, 667-679, 1999.

He, M. X., Liu, Z. S., Du, K. P., Li, L. P., Chen, R., Carder, K. L., and Lee, Z. P.: Retrieval of chlorophyll from remote-sensing reflectance in the China seas, Appl. Optics, 39, 2467-2474, 2000.

Herbland, A., Delmas, D., Laborde, P., Sautour, B., and Artigas, F.: Phytoplankton spring bloom of the Gironde plume waters in the Bay of Biscay: early phosphorus limitation and food-web consequences, Oceanol. Acta, 21, 279-291, 1998.

Hirata, T., Aiken, J., Hardman-Mountford, N., Smyth, T., and Barlow, R.: An absorption model to determine phytoplankton size classes from satellite ocean colour, Remote Sens. Environ., 112, 3153-3159, 2008.

Hirata, T., Hardman-Mountford, N., Brewin, R., Aiken, J., Barlow, R., Suzuki, K., Isada, T., Howell, E., Hashioka, T., and NoguchiAita, M.: Synoptic relationships between surface Chlorophylla and diagnostic pigments specific to phytoplankton functional types, Biogeosciences, 8, 311-327, doi:10.5194/bg-8-311-2011, 2011.

Hoge, F. E., Wright, C. W., Lyon, P. E., Swift, R. N., and Yungel, J. K.: Satellite retrieval of the absorption coefficient of phytoplankton phycoerythrin pigment: theory and feasibility status, Appl. Optics, 38, 7431-7441, 1999.

Ishizaka, J.: Spatial distribution of primary production off Sanriku, northwestern Pacific, during spring estimated by Ocean Color and Temperature Scanner (OCTS), J. Oceanogr., 54, 553-564, 1998.

Isobe, A., Ando, M., Watanabe, T., Senjyu, T., Sugihara, S., and Manda, A.: Freshwater and temperature transports through the Tsushima-Korea Straits, J. Geophys. Res., 107, C73065, doi:10.1029/2000jc000702, 2002.

Jiao, N., Yang, Y., Koshikawa, H., Watanabe, M.: Influence of hydrographic conditions on picoplankton distribution in the East China Sea, Aquat. Microb. Ecol., 30, 37-48, 2002.

Jiao, N., Yang, Y., Hong, N., Ma, Y., Harada, S., Koshikawa, H., and Watanabe, M.: Dynamics of autotrophic picoplankton and heterotrophic bacteria in the East China Sea, Cont. Shelf Res., 25, 1265-1279, 2005. 
Kameda, T., and Ishizaka, J.: Size-fractionated primary production estimated by a two-phytoplankton community model applicable to ocean color remote sensing, J. Oceanogr., 61, 663-672, 2005.

Kirk, J. T. O.: A theoretical analysis of the contribution of algal cells to the attenuation of light within natural waters II, Spherical cells, New Phytol., 75, 21-36, 1975.

Kishino, M., Takahashi, M., Okami, N., and Ichimura, S.: Estimation of the spectral absorption coefficients of phytoplankton in the sea, B. Mar. Sci., 37, 634-642, 1985.

Li, J., Glibert, P. M., Zhou, M., Lu, S., and Lu, D.: Relationships between nitrogen and phosphorus forms and ratios and the development of dinoflagellate blooms in the East China Sea, Mar. Ecol.-Prog. Ser., 383, 11-26, 2009.

Lohrenz, S. E., Weidemann, A. D., and Tuel, M.: Phytoplankton spectral absorption as influenced by community size structure and pigment composition, J. Plankton Res., 25, 35-61, 2003.

Matsuoka, A., Hill, V., Huot, Y., Babin, M., and Bricaud, A.: Seasonal variability in the light absorption properties of western Arctic waters: Parameterization of the individual components of absorption for ocean color applications, J. Geophys. Res., 116, C02007, doi:10.1029/2009jc005594, 2011.

Mitchell, B. G.: Algorithms for determining the absorption coefficient for aquatic particulates using the quantitative filter technique, in: SPIE. Ocean Opt. X, Orlando, United States, 1 September 1990, 1302, 137-148, 1990.

Mitchell, B. G., Kahru, M., Wieland, J., and Stramska, M.: Determination of spectral absorption coefficients of particles, dissolved material and phytoplankton for discrete water samples, Ocean optics protocols for satellite ocean color sensor validation, Revision, 3, 231-257, 2002.

Morel, A., and Bricaud, A.: Theoretical results concerning light absorption in a discrete medium, and application to specific absorption of phytoplankton, Deep-Sea Res. Pt. I, 28, 1375-1393, 1981.

Morel, A.: Optical modeling of the upper ocean in relation to its biogenous matter content (case I waters), J. Geophys. Res., 93, 10749-10768, 1988.

Morimoto, A., Takikawa, T., Onitsuka, G., Watanabe, A., Moku, M., and Yanagi, T.: Seasonal variation of horizontal material transport through the eastern channel of the Tsushima Straits, J. Oceanogr., 65, 61-71, 2009.

Odriozola, A. L., Varela, R., Hu, C., Astor, Y., Lorenzoni, L., and Müller-Karger, F. E.: On the absorption of light in the Orinoco River plume, Cont. Shelf Res., 27, 1447-1464, 2007.

Platt, T., and Sathyendranath, S.: Oceanic primary production: estimation by remote sensing at local and regional scales, Science, 241, 1613-1620, 1988.

Sathyendranath, S., Cota, G., Stuart, V., Maass, H., and Platt, T.: Remote sensing of phytoplankton pigments: A comparison of empirical and theoretical approaches, Int. J. Remote Sens., 22, 249-273, doi:10.1080/014311601449925, 2001.

Shen, Z. L.: Historical changes in nutrient structure and its influences on phytoplantkon composition in Jiaozhou Bay, Est. Coast. Shelf Sci., 52, 211-224, 2001.

Siswanto, E., Nakata, H., Matsuoka, Y., Tanaka, K., Kiyomoto, Y., Okamura, K., Zhu, J., and Ishizaka, J.: The long-term freshening and nutrient increases in summer surface water in the northern East China Sea in relation to Changjiang discharge variation, J. Geophys. Res., 113, C10030, doi:10.1029/2008jc004812, 2008.
Stæhr, P., Markager, S., and Sand-Jensen, K.: Pigment specific in vivo light absorption of phytoplankton from estuarine, coastal and oceanic waters, Mar. Ecol.-Prog. Ser., 275, 115-128, 2004.

Stuart, V., Sathyendranath, S., Platt, T., Maass, H., and Irwin, B. D.: Pigments and species composition of natural phytoplankton populations: effect on the absorption spectra, J. Plankton Res., 20, 187-217, 1998.

Suzuki, K., Kishino, M., Sasaoka, K., Saitoh, S., and Saino, T.: Chlorophyll-specific absorption coefficients and pigments of phytoplankton off Sanriku, Northwestern North Pacific, J. Oceanogr., 54, 517-526, 1998.

Uitz, J., Claustre, H., Morel, A., and Hooker, S. B.: Vertical distribution of phytoplankton communities in open ocean: An assessment based on surface chlorophyll, J. Geophys. Res., 111, C08005, doi:10.1029/2005jc003207, 2006.

Uitz, J., Huot, Y., Bruyant, F., Babin, M., and Claustre, H.: Relating phytoplankton photophysiological properties to community structure on large scales, Limnol. Oceanogr., 53, 614-630, 2008.

Van Heukelem, L., and Thomas, C. S.: Computer-assisted highperformance liquid chromatography method development with applications to the isolation and analysis of phytoplankton pigments, J. Chromatogr. A, 910, 31-49, 2001.

Vidussi, F., Claustre, H., Manca, B. B., Luchetta, A., and Marty, J. C.: Phytoplankton pigment distribution in relation to upper thermocline circulation in the eastern Mediterranean Sea during winter, J. Geophys. Res., 106, 19939-19956, 2001.

Wang, B., Wang, X., and Zhan, R.: Nutrient conditions in the Yellow Sea and the East China Sea, Estuar. Coast. Shelf S., 58, 127-136, doi:10.1016/s0272-7714(03)00067-2, 2003.

Yamaguchi, H., Kim, H. C., Son, Y. B., Kim, S. W., Okamura, K., Kiyomoto, Y., and Ishizaka, J.: Seasonal and summer interannual variations of SeaWiFS chlorophyll $a$ in the Yellow Sea and East China Sea, Prog. Oceanogr., 105, 22-29, doi:10.1016/j.pocean.2012.04.004, 2012.

Zhang, J., Liu, S. M., Ren, J. L., Wu, Y., and Zhang, G. L.: Nutrient gradients from the eutrophic Changjiang (Yangtze River) Estuary to the oligotrophic Kuroshio waters and re-evaluation of budgets for the East China Sea Shelf, Prog. Oceanogr., 74, 449478, doi:10.1016/j.pocean.2007.04.019, 2007.

Zhang, Y., Yin, Y., Wang, M., and Liu, X.: Effect of phytoplankton community composition and cell size on absorption properties in eutrophic shallow lakes: field and experimental evidence, Opt. Express, 20, 11882-11898, 2012.

Zhou, M., Shen, Z., and Yu, R.: Responses of a coastal phytoplankton community to increased nutrient input from the Changjiang (Yangtze) River, Cont. Shelf Res., 28, 1483-1489, doi:10.1016/j.csr.2007.02.009, 2008.

Zhu, Z. Y., Ng, W. M., Liu, S. M., Zhang, J., Chen, J. C., and Wu Y.: Estuarine phytoplankton dynamics and shift of limiting factors: A study in the Changjiang (Yangtze River) Estuary and adjacent area, Est. Coast. Shelf Sci., 84, 393-401, 2009. 